\title{
PENENTUAN FAKTOR-FAKTOR YANG MEMPENGARUHI GIZI BURUK ANAK BAWAH LIMA TAHUN DI PROVINSI SUMATERA BARAT DAN RIAU MENGGUNAKAN ANALISIS REGRESI KUANTIL
}

\author{
WAHYU ELFIYANA PUTRI, HAZMIRA YOZZA, IZZATI RAHMI HG \\ Program Studi Matematika, \\ Fakultas Matematika dan Ilmu Pengetahuan Alam, Universitas Andalas, \\ Kampus UNAND Limau Manis Padang, Indonesia, \\ email : wahyuelfiyanaputri@gmail.com
}

\begin{abstract}
Abstrak. Gizi buruk adalah kondisi kekurangan energi dan protein tingkat berat akibat kurang mengkonsumsi makanan yang bergizi dan menderita sakit yang begitu lama. Gizi buruk umumnya terjadi pada anak usia di bawah lima tahun (Balita) yang disebabkan oleh banyak faktor. Penelitian ini dilakukan untuk menentukan faktor-faktor yang berpengaruh signifikan terhadap gizi buruk balita. Data yang digunakan adalah data gizi buruk balita Provinsi Sumatera Barat dan Riau tahun 2014. Analisis dilakukan dengan analisis regresi kuantil. Diperoleh faktor yang mempengaruhi gizi buruk adalah penduduk yang mempunyai akses air minum memenuhi syarat, posyandu yang aktif, bayi 0 - 6 bulan diberi ASI eksklusif, pemberian vitamin A pada bayi 6 - 11 bulan dan pelayanan kesehatan anak balita.
\end{abstract}

Kata Kunci: Gizi buruk, balita, regresi kuantil

\section{Pendahuluan}

Salah satu ciri bangsa yang maju adalah mempunyai derajat kesehatan yang tinggi karena derajat kesehatan berpengaruh terhadap kualitas Sumber Daya Manusia (SDM). Terdapat tiga indikator dalam memantau derajat kesehatan, salah satunya adalah status gizi. Jika zat nutrisi yang masuk ke dalam tubuh tidak seimbang dalam jangka waktu yang lama dapat menimbulkan masalah kesehatan seperti gizi buruk. Pada tahun 2013, prevalensi kekurangan gizi pada anak balita secara nasional meningkat menjadi 19,6\% dibandingkan tahun 2007 (18,4\%) dan 2010 (17,9\%). Dari 33 provinsi di Indonesia terdapat 19 provinsi yang memiliki prevalensi anak balita kekurangan gizi di atas angka prevalensi nasional, dua provinsi diantaranya adalah Provinsi Sumatera Barat dan Riau [4].

Banyak faktor penyebab terjadinya gizi buruk anak balita. Berdasarkan faktorfaktor penyebab gizi buruk tersebut, dengan menggunakan analisis regresi dapat ditentukan faktor yang berpengaruh signifikan terhadap gizi buruk anak balita. Analisis regresi dapat digunakan jika asumsi-asumsi dalam penggunaan analisis regresi telah terpenuhi. Jika salah satu asumsi tidak terpenuhi maka analisis regresi tidak dapat digunakan. Pada kondisi ini analisis yang dapat digunakan adalah analisis regresi kuantil. 


\section{Tinjauan Teori}

\subsection{Analisis Regresi Linear}

Analisis regresi adalah analisis yang digunakan untuk memodelkan hubungan antara variabel respon dengan satu atau lebih variabel prediktor. Secara umum model regresi linear adalah :

$$
Y=\beta_{0}+\beta_{1} X_{1}+\beta_{2} X_{2}+\cdots+\beta_{p} X_{p}+\varepsilon
$$

$\begin{array}{lll} & & \\ \operatorname{dimana}: & \text { variabel respon } \\ X_{1}, X_{2}, \cdots, X_{p} & : & \text { variabel prediktor } \\ \beta_{0}, \beta_{1}, \cdots, \beta_{p} & : & \text { koefisien regresi } \\ \varepsilon & : & \text { error }\end{array}$

Model analisis regresi sebagaimana pada Persamaan 2.1 adalah model untuk populasi. Model ini diduga dengan model regresi sampel. Model regresi sampel untuk analisis regresi adalah :

$$
y=b_{0}+b_{1} x_{1}+b_{2} x_{2}+\cdots+b_{p} x_{p}+e
$$

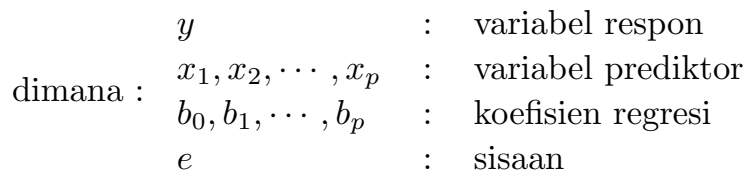

Terdapat beberapa cara untuk menduga koefisien regresi. Salah satunya adalah dengan Metode Kuadrat Terkecil (MKT). Prinsip dari Metode Kuadrat Terkecil adalah meminimumkan jumlah kuadrat sisaan (JKS).

Model regresi yang diperoleh dari Metode Kuadrat Terkecil merupakan suatu model regresi yang dapat memberikan nilai estimasi atau prakiraan linier tidak bias yang paling baik. Agar kondisi tersebut diperoleh, terdapat beberapa asumsi yang harus dipenuhi :

(1) $X$ bukan peubah acak.

(2) $\varepsilon_{1}, \varepsilon_{2}, \cdots, \varepsilon_{n}$ adalah peubah acak yang saling bebas yang menyebar normal dengan $E\left(\varepsilon_{i}\right)=0$ dan $\operatorname{Var}\left(\varepsilon_{i}\right)=\sigma$.

Oleh karena itu harus dilakukan uji terhadap asumsi. Berikut adalah uji yang digunakan dalam asumsi klasik:

(1) Uji Normalitas dilakukan untuk mengetahui apakah data menyebar normal dengan menggunakan Uji Shapiro-Wilk. Uji Shapiro-Wilk dianggap lebih akurat digunakan jika data kurang dari 50 [3].

(2) Uji Heteroskedastisitas untuk menguji apakah terjadi heteroskedastisitas pada suatu data. Uji ini dapat dilakukan dengan Uji Breusch-Pagan.

(3) Uji Autokorelasi dilakukan untuk mendeteksi masalah autokorelasi dengan menggunakan uji Durbin-Watson.

(4) Pemeriksaan Multikolinearitas dapat dilakukan dengan melihat nilai VIF ( Variance Inflation Factor). 


\subsection{Regresi Kuantil}

Regresi kuantil pertama kali dikenalkan oleh Koenker dan Basset (1978), model regresi kuantil dianggap perluasan dari model metode kuadrat terkecil. Regresi kuantil dilakukan dengan membagi data menjadi beberapa kelompuk berdasarkan kuantil dari sebaran data kemudian melakukan estimasi pada masing-masing kelompok data. Berikut merupakan model linear dari regresi kuantil:

$$
Y_{i}=\beta_{0}+X_{i 1} \beta_{1}(\theta)+X_{i 2} \beta_{2}(\theta)+\cdots+X_{i p} \beta_{p}(\theta)+\varepsilon_{i} .
$$

Peubah acak $Y$ dengan fungsi sebaran kumulatif $F(y)=P(Y \leq y)$, dimana untuk setiap $0 \leq \theta \leq 1$,

$$
F_{Y}^{-1}(\theta)=\inf \left\{y: F_{Y}(y) \geq \theta\right\}
$$

disebut kuantil ke- $\theta$ dari $Y[5]$. Fungsi kuantil dilambangkan dengan $Q_{\theta}$ sehingga kuantil bersyarat ke- $\theta$ dari $Y$ didefinisikan

$$
Q_{\theta}(Y \mid X=x)=\inf \left\{y: F_{Y}(y \mid x) \geq \theta\right\} .
$$

Koenker menganalisa kasus regresi kuantil dengan melihat masalah regresi sebagai masalah dalam menduga rata-rata berdasarkan data contoh, dimana nilai tengah $\mu$ diperoleh sedemikian sehingga [7]:

$$
\min _{\mu \in R} \sum_{i=1}^{n}\left(y_{i}-\mu\right)^{2}
$$

Hal ini berarti bahwa nilai dugaan $\mu$ diperoleh dengan cara meminimumkan jumlah kuadrat selisih antara data dengan rata-ratanya. Jika $\mu=x^{\prime} \beta$ maka Persamaan 2.6 menjadi :

$$
\min _{\beta \in R^{p}} \sum_{i=1}^{n}\left(y_{i}-x_{i}^{\prime} \beta\right)^{2}
$$

Selanjutnya model berkembang menjadi median contoh yang dinyatakan :

$$
\min _{\beta \in R^{p}} \sum_{i=1}^{n}\left|y_{i}-\widehat{y}_{i}\right|
$$

Berdasarkan konsep median penduga bagi $\beta$ dari regresi kuantil ke- $\theta$ diperoleh dengan meminimumkan jumlah nilai mutlak dari error dengan pembobot $\theta$ untuk error positif dan pembobot $(1-\theta)$ untuk error negatif [6]:

$$
\min _{x_{i}^{\prime} \beta_{\theta} \in R}\left\{\sum_{i \in i \mid y_{i} \geq x_{i}^{\prime} \beta(\theta)} \theta\left|y_{i}-x_{i}^{\prime} \beta(\theta)\right|+\sum_{i \in i \mid y_{i}<x_{i}^{\prime} \beta(\theta)}(1-\theta)\left|y_{i}-x_{i}^{\prime} \beta(\theta)\right|\right\} .
$$

Atau dapat juga ditulis dalam persamaan berikut :

$$
\min _{\beta \in R^{p}} \sum_{i=1}^{n} \rho_{\theta}\left(y_{i}-x_{i}^{\prime} \beta(\theta)\right) \text {. }
$$




\section{Data dan Pembahasan}

Data yang digunakan dalam penelitian ini adalah data sekunder yang diperoleh dari Profil Kesehatan 2014 Provinsi Sumatera Barat [2], Profil Kesehatan Provinsi Riau 2014 [1] dan Data Status Lingkungan Hidup Daerah Tahun 2014 [8]. Unit pengamatan terdiri dari 31 Kabupaten/Kota di Provinsi Sumatera Barat dan Riau.

Variabel yang digunakan terdiri dari variabel respon yaitu persentase gizi buruk anak balita $(Y)$ dan variabel prediktor yaitu persentase penduduk yang mempunyai akses air minum memenuhi syarat $\left(X_{1}\right)$, persentase penduduk yang mempunyai akses jamban $\left(X_{2}\right)$, persentase posyandu yang aktif $\left(X_{3}\right)$, persentase bayi $0-6$ bulan diberi ASI eksklusif $\left(X_{4}\right)$, persentase pemberian Vitamin A pada bayi $6-11$ bulan $\left(X_{5}\right)$, persentase penimbangan anak balita $\left(X_{6}\right)$, dan persentase pelayanan kesehatan anak balita $12-59$ bulan $\left(X_{7}\right)$.

Berdasarkan uji asumsi klasik yang telah dilakukan diperoleh dua asumsi yang tidak terpenuhi yaitu asumsi normalitas dan asumsi hete-roskedastisitas. Selanjutnya akan digunakan regresi kuantil untuk melihat variabel prediktor apa saja yang berpengaruh signifikan terhadap variabel respon. Berikut merupakan hasil estimasi parameter regresi kuantil pada nilai kuantil $0,10,0,20,0,30,0,40,0,50,0,60,0,70,0,80$, dan 0,90 :

Tabel 3.1 Hasil Estimasi Parameter Regresi Kuantil

\begin{tabular}{|c|c|c|c|c|c|c|c|c|c|}
\hline \multirow{2}{*}{ Parameter } & \multicolumn{3}{|c|}{ Kuantil 0.4 } & \multicolumn{3}{c|}{ Kuantil 0.5} & \multicolumn{3}{c|}{ Kuantil 0.6 } \\
\cline { 2 - 10 } & Nilai Koefisien & $\begin{array}{c}\text { Standar } \\
\text { Deviasi }\end{array}$ & $p$-value & Nilai Koefisien & $\begin{array}{c}\text { Standar } \\
\text { Deviasi }\end{array}$ & $p$-value & Nilai Koefisien & $\begin{array}{c}\text { Standar } \\
\text { Deviasi }\end{array}$ & $p$-value \\
\hline$\beta_{0}$ & 0.01591 & 0.10398 & 0.88 & 0.05418 & 0.07824 & 0.49 & 0.01917 & 0.09008 & 0.83 \\
\hline$\beta_{1}$ & 0.0018 & 0.001 & $0.09^{*}$ & 0.00132 & 0.00075 & $0.09^{*}$ & 0.00152 & 0.00087 & $0.09^{*}$ \\
\hline$\beta_{2}$ & -0.00098 & 0.0013 & 0.46 & -0.00021 & 0.00098 & 0.83 & -0.00023 & 0.00112 & 0.84 \\
\hline$\beta_{3}$ & -0.00067 & 0.00081 & 0.42 & -0.00009 & 0.00061 & 0.89 & -0.00036 & 0.0007 & 0.62 \\
\hline$\beta_{4}$ & 0.00206 & 0.00147 & 0.17 & 0.00107 & 0.0011 & 0.34 & 0.00127 & 0.00127 & 0.33 \\
\hline$\beta_{5}$ & -0.00108 & 0.00075 & 0.16 & -0.00114 & 0.00056 & $0.06^{*}$ & -0.00085 & 0.00065 & 0.21 \\
\hline$\beta_{6}$ & -0.00099 & 0.00157 & 0.53 & -0.0006 & 0.00118 & 0.62 & 0.0003 & 0.00136 & 0.83 \\
\hline$\beta_{7}$ & 0.00051 & 0.00121 & 0.68 & 0.00011 & 0.00091 & 0.90 & -0.00046 & 0.00105 & 0.67 \\
\hline
\end{tabular}

\begin{tabular}{|c|c|c|c|c|c|c|c|c|c|}
\hline \multirow{2}{*}{ Parameter } & \multicolumn{3}{|c|}{ Kuantil 0.4 } & \multicolumn{3}{c|}{ Kuantil 0.5 } & \multicolumn{3}{c|}{ Kuantil 0.6 } \\
\cline { 2 - 10 } & Nilai Koefisien & $\begin{array}{c}\text { Standar } \\
\text { Deviasi }\end{array}$ & $p$-value & Nilai Koefisien & $\begin{array}{c}\text { Standar } \\
\text { Deviasi }\end{array}$ & $p$-value & Nilai Koefisien & $\begin{array}{c}\text { Standar } \\
\text { Deviasi }\end{array}$ & $p$-value \\
\hline$\beta_{0}$ & 0.01591 & 0.10398 & 0.88 & 0.05418 & 0.07824 & 0.49 & 0.01917 & 0.09008 & 0.83 \\
\hline$\beta_{1}$ & 0.0018 & 0.001 & $0.09^{*}$ & 0.00132 & 0.00075 & $0.09^{*}$ & 0.00152 & 0.00087 & $0.09^{*}$ \\
\hline$\beta_{2}$ & -0.00098 & 0.0013 & 0.46 & -0.00021 & 0.00098 & 0.83 & -0.00023 & 0.00112 & 0.84 \\
\hline$\beta_{3}$ & -0.00067 & 0.00081 & 0.42 & -0.00009 & 0.00061 & 0.89 & -0.00036 & 0.0007 & 0.62 \\
\hline$\beta_{4}$ & 0.00206 & 0.00147 & 0.17 & 0.00107 & 0.0011 & 0.34 & 0.00127 & 0.00127 & 0.33 \\
\hline$\beta_{5}$ & -0.00108 & 0.00075 & 0.16 & -0.00114 & 0.00056 & $0.06^{*}$ & -0.00085 & 0.00065 & 0.21 \\
\hline$\beta_{6}$ & -0.00099 & 0.00157 & 0.53 & -0.0006 & 0.00118 & 0.62 & 0.0003 & 0.00136 & 0.83 \\
\hline$\beta_{7}$ & 0.00051 & 0.00121 & 0.68 & 0.00011 & 0.00091 & 0.90 & -0.00046 & 0.00105 & 0.67 \\
\hline
\end{tabular}




\begin{tabular}{|c|c|c|c|c|c|c|c|c|c|}
\hline \multirow{2}{*}{ Parameter } & \multicolumn{3}{|c|}{ Kuantil 0.7} & \multicolumn{3}{c|}{ Kuantil 0.8} & \multicolumn{3}{c|}{ Kuantil 0.9 } \\
\cline { 2 - 10 } & Nilai Koefisien & $\begin{array}{c}\text { Standar } \\
\text { Deviasi }\end{array}$ & $p$ - value & Nilai Koefisien & $\begin{array}{c}\text { Standar } \\
\text { Deviasi }\end{array}$ & $p$-value & Nilai Koefisien & $\begin{array}{c}\text { Standar } \\
\text { Deviasi }\end{array}$ & $p$ - value \\
\hline$\beta_{0}$ & 0.0676 & 0.08559 & 0.44 & 0.47874 & 0.25593 & 0.07 & 0.61263 & 0.21501 & 0.01 \\
\hline$\beta_{1}$ & 0.00266 & 0.00083 & $0.003^{*}$ & 0.00391 & 0.00247 & 0.13 & 0.00641 & 0.00207 & $0.005^{*}$ \\
\hline$\beta_{2}$ & 0.00022 & 0.00107 & 0.84 & 0.00177 & 0.0032 & 0.59 & 0.00117 & 0.00268 & 0.67 \\
\hline$\beta_{3}$ & -0.00132 & 0.00067 & $0.06^{*}$ & -0.00344 & 0.00199 & $0.09^{*}$ & -0.00443 & 0.00167 & $0.01^{*}$ \\
\hline$\beta_{4}$ & 0.00101 & 0.00121 & 0.41 & -0.00267 & 0.00361 & 0.47 & -0.00191 & 0.00303 & 0.53 \\
\hline$\beta_{5}$ & -0.00084 & 0.00062 & 0.19 & -0.00213 & 0.00185 & 0.26 & -0.00441 & 0.00155 & $0.009^{*}$ \\
\hline$\beta_{6}$ & 0.00039 & 0.00129 & 0.77 & 0.00425 & 0.00386 & 0.28 & 0.00239 & 0.00324 & 0.47 \\
\hline$\beta_{7}$ & -0.00124 & 0.001 & 0.23 & -0.00528 & 0.00298 & $0.09^{*}$ & -0.00405 & 0.0025 & 0.12 \\
\hline
\end{tabular}

(*) signifikan pada taraf $\alpha=0,1$

Pada taraf $\alpha=0,1$ persentase penduduk yang mempunyai akses air minum memenuhi syarat $\left(X_{1}\right)$ dan persentase bayi $0-6$ bulan diberi ASI eksklusif $\left(X_{4}\right)$ berpengaruh signifikan pada kuantil ke-0,10 dan 0,20. Persentase penduduk yang mempunyai akses air minum memenuhi syarat $(X 1)$ variabel prediktor yang berpengaruh signifikan adalah pada kuantil ke-0,30,0, 40 dan 0,60. Pada kuantil ke-0, 50 variabel prediktor yang berpengaruh signifikan adalah persentase penduduk yang mempunyai akses air minum memenuhi syarat $\left(X_{1}\right)$ dan persentase pemberian vitamin A pada bayi $6-11$ bulan $\left(X_{5}\right)$. Pada kuantil ke- 0,70 variabel prediktor yang berpengaruh signifikan adalah persentase penduduk yang mempunyai akses air minum memenuhi syarat $\left(X_{1}\right)$ dan persentase posyandu yang aktif $\left(X_{3}\right)$. Pada kuantil ke-0, 80 persentase posyandu yang aktif $\left(X_{3}\right)$ dan persentase pelayanan kesehatan anak balita $\left(X_{7}\right)$ merupakan variabel prediktor yang berpengaruh signifikan. Untuk kuantil ke-0,90 variabel prediktor yang berpengaruh signifikan adalah persentase penduduk yang mempunyai akses air minum memenuhi syarat $\left(X_{1}\right)$, persentase posyandu yang aktif $\left(X_{3}\right)$ dan persentase pemberian vitamin A pada bayi $6-11$ bulan $\left(X_{5}\right)$.

\section{Kesimpulan}

Berdasarkan hasil dan pembahasan yang telah dilakukan dapat disimpulkan bahwa variabel prediktor yang berpengaruh signifikan terhadap variabel respon gizi buruk anak balita $(Y)$ adalah persentase penduduk yang mempunyai akses air minum memenuhi syarat $\left(X_{1}\right)$, persentase posyandu yang aktif $\left(X_{3}\right)$, persentase bayi 06 bulan diberi ASI eksklusif $\left(X_{4}\right)$, persentase pemberian vitamin A pada bayi $6-11$ bulan $\left(X_{5}\right)$ dan persentase pelayanan kesehatan anak balita $\left(X_{7}\right)$.

\section{Ucapan Terima kasih}

Penulis mengucapkan terima kasih kepada Dr. Ferra Yanuar, Bapak Budi Rudianto, M.Si dan Bapak Dr. Ahmad Iqbal Baqi yang telah memberikan masukan dan saran sehingga paper ini dapat diselesaikan dengan baik. 


\section{Daftar Pustaka}

[1] Dinas Kesehatan Provinsi Riau. 2014. Profil Kesehatan Provinsi Riau 2014. Dinas Kesehatan Provinsi Riau, Pekanbaru

[2] Dinas Kesehatan Provinsi Sumatera Barat. 2015. Profil Kesehatan 2014 Provinsi Sumatera Barat. Dinas Kesehatan Provinsi Sumatera Barat, Padang

[3] Hidayat, A. 2014. Shapiro Wilk Tabel (Tabel Shapiro Wilk). https://www.statistikian.com/2014/03/shapiro-wilk-tabel.html, 4 April 2017

[4] Kementerian Kesehatan RI. 2014. Profil Kesehatan Indonesia Tahun 2013. Kementerian Kesehatan Republik Indonesia, Jakarta

[5] Koenker, R. 2005. Quantile Regression. Cambridge University Press. Inggris

[6] Koenker, R., \& Bassett, G. 1978. Regression Quantiles. Econometrica: Journal of the Econometric Society, 46(1): $33-50$

[7] Koenker, R., \& Hallock, K. F. 2001. Quantile Regression: An Introduction. The Journal of Economic Perspectives, 15(4): 143 - 156

[8] Pemerintah Provinsi Sumatera Barat. 2015. Data Status Lingkungan Hidup Daerah Tahun 2014. Bapedalda Provinsi Sumatera Barat, Padang 